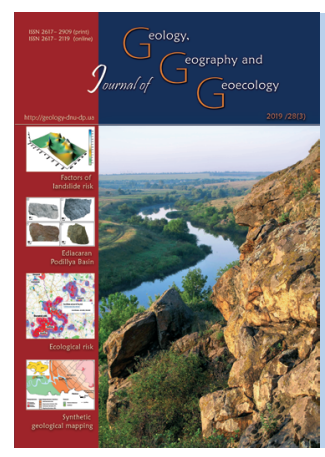

Journal of Geology,

\title{
Effect of Land Use/Land Cover Change on Groundwater Recharge in Osun Drainage Basin, Nigeria
}

\author{
E. D. Ashaolu*, J. F. Olorunfemi, I. P. Ifabiyi
}

Department of Geography and Environmental Management, Faculty of Social Sciences, University of Ilorin, Ilorin, Nigeria,*damash007@yahoo.com

Received: 23.01.2019

Received in revised form: 16.02 .2019

Accepted: 17.04.2019 Abstract. Abstract. Osun drainage basin is one of the regions in Nigeria experiencing
increasing population growth and rapid urbanization; and about $70 \%$ of the inhabitants
rely on shallow groundwater resources of the region. Change in land use/land cover is one
of the significant factors controlling regional hydrology and groundwater resources, thus the continuous change in land use and land cover of the drainage basin will significantly affect the basin's groundwater resources. There are 7 classified land use/land cover in the study area which are bare surfaces, built up area, crops/shrubs, forest, rock outcrops, water bodies and wetland. Applying WetSpass-M hydrological model, we predicted the effect of land use/land cover change on the groundwater recharge in Osun drainage basin, Nigeria between 1984-2015. The results revealed that the highest groundwater recharge of $48.56 \%, 33.64 \%$ and $37.29 \%$ occurred in forested area in 1984, 2000 and 2015, respectively. This result might be due to the influence of vegetation in slowing down the speed of running water across the forest area, that allows more infiltration and deep percolation into the water table to recharge the groundwater system. On the other hand, the least groundwater recharge of the total annual was on the rock outcrops, which are about 4\% in 1984, 3\% in 2000 and 2\% in 2015. The least recharge found on rock outcrops is expected and may be attributed to the fact that infiltration can only occur around or on decomposed rock outcrop, which may result in minute recharge to the groundwater system. The mean annual groundwater recharge of the basin for the land use/land cover of 1984, 2000 and 2015 are $476.54,411.07$ and $430.06 \mathrm{~mm} / \mathrm{y}$, respectively. Overall, for the 32 years period of investigation, change in land use/land cover accounts for only 10\% reduction in mean groundwater recharge occurrence between 1984 and 2015. Also, there is a change in recharge pattern in the study area during this period because most often, change in land use/land cover is a transition from one land use/land cover class to another, and the recharge pattern is influenced based on the degree of transition that took place and the characteristics of the dominant land use/land cover at a particular area of the basin. Although, the $10 \%$ reduction in mean annual recharge appears minute, this might become pronounced if the current rate of deforestation in the drainage basin continues unabated. Therefore, proper land use allocation, regulated land development and afforestation in terms of planting of native trees that were lost through anthropogenic activities in the basin should be policy option for groundwater sustainability.

Keywords: Land use and land cover, Groundwater, recharge, WetSpass, Osun drainage basin

\section{Вплив землекористування (зміни земного покриву) на поповнення запасів підземних вод в басейні річки Осун, Нігерія}

\author{
Е. Д. Ашаолу*, Дж. Ф. Олорунфемі, І. П. Іфабії
}

Кафедра географії управління навколишнім середовищем, факультет соиіальних наук, Університет Ілорін, Hizерія, *damash007@yahoo.com Анотація. Перші зВодосховище Осуна є одним з регіонів Нігерії, де спостерігається зростання населення і швидка
урбанізація; і близько 70\% жителів покладаються на неглибокі ресурси грунтових вод регіону. Зміна умов землекористування
$€$ одним з важливих факторів, що контролюють регіональну гідрологію та ресурси підземних вод. Таким чином, безперервна
зміна використання землі та земельного покриву водозбірного басейну суттєво впливає на ресурси грунтових вод басейну. У
досліджуваному районі $є 7$ класифікованих земельних ділянок (землекористування), якими є відкриті поверхні, забудовані
території, сільськогосподарські угіддя, чагарники, ліси, відслонення гірських порід, водоймища та водно-болотні угіддя. За-
стосовуючи гідрологічну модель WetSpass-M, ми прогнозували вплив зміни землекористування на живлення підземних вод 
в басейні водосховища Осун (Нігерія) в період з 1984 по 2015 рік. Результати показали, що найбільша поповнення підземних вод 48,56\%, 33,64\% та 37,29\% відбулося у лісовій зоні у 1984, 2000 та 2015 роках відповідно. Цей результат може бути зумовлений впливом рослинності на уповільнення швидкості просочування води через лісову підстилку. 3 іншого боку, найменше поповнення підземних вод у загальному обсязі річного видобутку відбувалося на виходах гірських порід, які становили близько 4\% у 1984 році, $3 \%$ у 2000 році та $2 \%$ у 2015 році. Очікується найменше поповнення, виявлене на відкритих скелях, і може бути пов'язане з тим, що інфільтрація може відбуватися тільки навколо або на звітрених, дезінтегрованих ділянках порід, що може призвести до короткочасного поповнення системи підземних вод. Середньорічне поповнення підземних вод у басейні для землекористування (земного покриву) у 1984, 2000 та 2015 років становить 476,54, 411,07 та 430,06 мм / год відповідно. В цілому, протягом 32-річного періоду досліджень, зміна землекористування (земного покриву) дає лише $10 \%$ скорочення середнього рівня живлення підземних вод у період з 1984 по 2015 рік. Найчастіше, зміна землекористування - це перехід від одного класу землекористування до іншого, і схема поповнення залежать від ступеня переходу, що мав місце, $\mathrm{i}$ характеристик домінуючого землекористування на певній території басейну. Хоча, $10 \%$ скорочення середнього щорічного живлення з'являється хвилини, це може стати яскраво вираженим, якщо нинішня швидкість вирубки лісів у водозбірному басейні продовжується. Таким чином, належне ведення землекористування, регульоване освоєння земель та лісорозведення 3 посадкою районованих дерев, які були втрачені внаслідок антропогенної діяльності в басейні, має бути політичним рішенням проблеми забезпечення стійкості підземних вод.

Ключові слова: землекористування та земний покрив, підземні води, живлення, WetSpass, Осунський дренажний басейн

Introduction. Change in land use/land cover (LULC) is an important factor influencing the groundwater system. Since the beginning of industrialization, intensive anthropogenic activities that include agriculture, urbanization mining, etc. have consequently resulted to alteration of the physical landscape with effect on the regional water balance of surface and groundwater systems (Bronstert, 2004; Albhaisi, et al., 2013). Land use type and the native land cover of any particular area influence water as it moves through a drainage, which can change downstream delivery via ecosystem interactions such as rainfall interception, evapotranspiration rate, macropore development, and environmental filtration (Brauman et al., 2007). The connection between land use and water resources is of significant importance to groundwater governance and management, mainly because change in land use can have a life time effects on groundwater and some land use change events can have an unredeemable influence on aquifers and groundwater storage (Foster and Cherlet, 2014). As a matter of fact, the rate at which the natural landscape is changing as a result of population increase, urbanization, various anthropogenic activities and the large-scale conversion of land from a particular use to another is alarming all over the world.

Sala et al. (2000) and Vorosmarty et al., (2000) had earlier reported that the impacts of land-use change on the world water resources and ecosystem biodiversity may surpassed that of climate change in the $21^{\text {st }}$ century. The implications of land use change that include: changes in land use practices and its associated changes in water demand, irrigation projects and urbanization; changes in water supply from modified hydrological processes of infiltration, groundwater recharge and runoff; and changes in water quality from agricultural runoff and suburban development should be fully understood (DeFries and Eshleman, 2004) and of necessity integrated into the emerging land use change science of the future (Turner et al., 2003; DeFries and Eshleman, 2004). However, despite the evidences that abound that every decision made on land use practice has an impression on water resources, it is yet to be largely incorporated into integrated management practices by policy makers (IFAD, 2010 cited in Foster and Cherlet, 2014). Therefore, in order to protect and enhance water resources generally, and groundwater in particular, managers need to know and understand how land-use decisions and allocation will impact on the flow of water (Brauman et al., 2012).

In recent years, some studies have tried to evaluate the effect of LULC change on groundwater resources around the world. For example, Zamlot et al., (2015) predicted the effect of LULC on groundwater recharge in Flinders, Belgium and they discovered that forest land-use type has a positive higher effect on groundwater recharge. Albhaisi et al. (2013) also examined the effect of LULC change on groundwater recharge in upper Berg catchment, South Africa. They discovered that groundwater recharge on bare LULC class increases significantly from 23\% in 1984 to $64.7 \%$ in 2008 . The influence of LULC change on groundwater recharge was investigated by Dams et al. (2008) in Kleine Nete Catchment, Belgium. They adopted four LULC change between 2000 and 2020. They observed that recharge reduced in urban centres in all the land use change scenarios. Pan et al. (2011) investigated the hydrological processes and recharge ability of various land use types in Guishui River Basin, China. They discovered that the annuallumped groundwater recharge rate decreases in the order of cropland, grassland, urban land, and forest, which has resulted in a decrease of $4 \times 106 \mathrm{~m}^{3} /$ year of groundwater recharge between 1980 and 2005 . They attributed the decrease in groundwater recharge 
observed to an increase in urban area and rural settlements; and decrease in cropland land use class.

Most of the studies on the effect of land-use change on groundwater research has principally focused on the change in water quality thereby neglecting changes in quantity (Dam et al., 2008), and this is the scenario in the Nigeria context. The scarcity of the studies on effect of land use on groundwater quantity in Nigeria are closely related to the views of De Fries and Eshleman (2004), that evaluating the effect of land use change on groundwater quantity is complicated by the comparatively short lengths of hydrological records; the comparatively high natural variability of most hydrological systems; and the difficulties in controlling land-use changes in real catchments within which changes are taking place. In addition, the complex nature of groundwater hydrology, the complexities of its interaction with the ecosystem, and the inadequate record on hydrological processes made such study scarce in Nigeria. Meantime the recent advancement in Satellite remote sensing data collection and the improvement in modelling of hydrological processes have made the study more feasible. However, embracing the advancement in these technologies to quantify the effect of changing land use on groundwater quantity is still evolving in Nigeria. Therefore, this present study attempts to predict the effect of land use and land cover change on groundwater recharge in Osun drainage basin (Nigeria) using satellite remote sensing data and WetSpass-M hydrological model.

Osun drainage basin is one of the two major drainage basins in the southwestern Nigeria, and it cut across about six states. About seventy-five percent of the inhabitants of the basin depend on groundwater as a source of water for their domestic consumption. Osun drainage basin is an area naturally characterized by rainforest vegetation. The natural vegetation, has however, been replaced by secondary forest due to many years of anthropogenic activities through vegetation clearing and increasing urbanization (Ifabiyi, 2005). The basin has witnessed one of the fastest rates of forest conversion and change in vegetation in Nigeria. This is as a consequence of fuel wood production, road construction, clay/sand quarrying, widespread rotational bush farming, as well as high rate of emerging cities. In fact, the population of the area has been increasing and the urban centres located therein are growing rapidly. Studies on LULC in different parts of the drainage basin have suggested rapid changes in LULC all over the basin (Gasu, et al. 2016; Mengistu and Salami, 2007; Akinyemi, 2005; Salami et al., 1999; Salami, 1995), which will impact the water balance of the basin.
All these changes in land use/land cover will have significant feedback on the water balance of the basin. The groundwater resources of the drainage area will be influenced by the prevailing incidences of LULC change. This might stress the existing groundwater supply, with increasing risk of reduced groundwater recharge. Consequently, the ability of the groundwater system to meet the increasing water need now, in the future and sustaining the ecosystem will be at greater risk. This study will assist in understanding the implications of LULC change on groundwater resources in Osun drainage basin and it will inform land use allocation and management within the basin that will discourage unregulated and uncontrolled land use development that may pose great risk to groundwater system in particular and the environment in general. Meanwhile, the manifestation of a declining groundwater resource was observed in the upper part of the Osun drainage basin more than three decades ago (Omorinbola, 1982). The decline, attributed to the level of urbanization, number of well per unit area and the clearing of rainforest for commercial scale agriculture, as of that time has witnessed tremendous urbanization with emerging cities such as Osogbo, Ede, Ilesha, Ikirun, Iwo, Ogbomosho, Oke Imesi, etc. expanding in leaps and bounds. With population increase, no doubt, more vegetation has been cleared to give way for urbanization, hence, predicting the effect of such change on LULC will enhance sustainable groundwater management in the drainage basin. Study Area. The study area is located between latitudes $6^{\circ} 25^{\prime} 58.79^{\prime \prime}$ and $8^{\circ} 21^{\prime} 3.6^{\prime \prime} \mathrm{N}$ and longitudes $3^{\circ} 47^{\prime} 34.8^{\prime \prime}$ and $5^{\circ} 10^{\prime} 55.2^{\prime \prime} \mathrm{E}$ in the southwestern Nigeria (Figure 1). River Osun which is the major river in the drainage system accents in Oke-Mesi ridge, about $5 \mathrm{~km}$ North of Effon Alaiye and flows North across the Itawure gap to latitude $7^{\circ} 53^{\prime \prime}$ and then deviates westwards via Osogbo, Ede and southwards to flow into Lagos lagoon (Oke, et. al., 2013; Ashaolu, 2016; Ogun-Oshun River Basin Development Authority [OORBDA], 1982). The basin climate is influenced by the movement of the Inter-tropical Convergence Zone (ITCZ), the quazi-stationary boundary that distinguishes the sub-tropical continental air mass over the Sahara and the equatorial maritime air mas over the Atlantic Ocean (OORBDA, 1982). The climate of the basin can be described as the tropical continental climate of Koppen Aw type humid tropical rainforest climate (Ifabiyi, 2005). The basin experiences two types of seasons, dry and rainy (wet) season. The switch from the rainy season to the dry season is abrupt, while the onset of the rain after the dry season is gradual (OORBDA, 1982). 


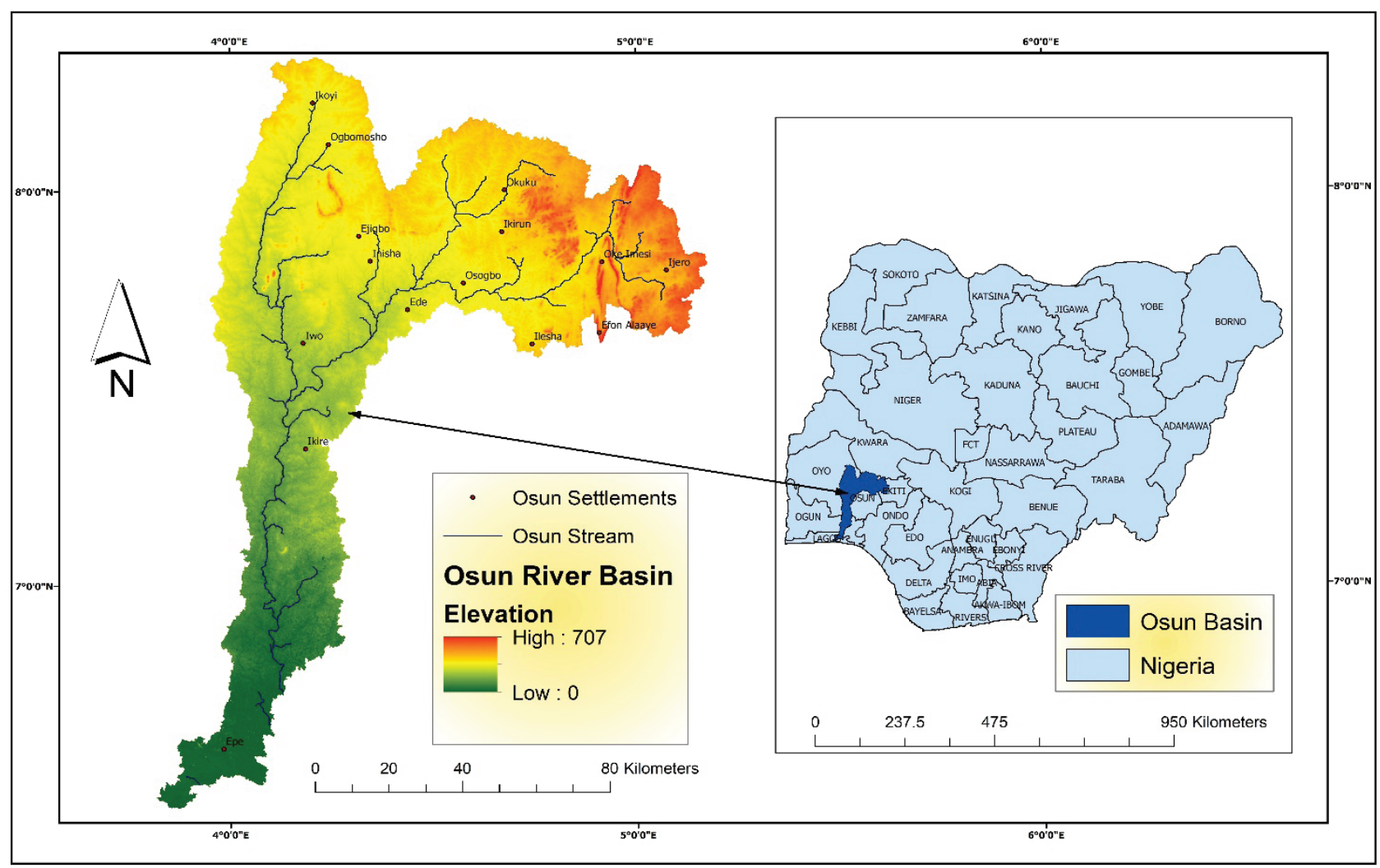

Fig. 1 Location and Position of Osun Drainage Basin, Nigeria. Source: Modified from Ashaolu (2016)

The rainy season begins earlier in the south around March and continues until the end of October or early November. In the north around Ogbomosho, the rain begins in late April or early May and end in mid-October, giving six months of rainfall. The mean wet season rainfall varies from $1,020 \mathrm{~mm}$ to $1,520 \mathrm{~mm}$ in the south of the basin and less than $1,020 \mathrm{~mm}$ in the north. On the other hand, the mean dry season rainfall varies from 127 to $178 \mathrm{~mm}$ in the north, while it varies from 178 to $254 \mathrm{~mm}$ in the south (OORBDA, 1982). The months of February and March are the hottest in the basin and temperatures are high over the entire basin during this period. There is also variation in temperature from the south to the north, where it higher. The lowest mean minimum temperature in the north is usually in December during Harmattans, while it is usually recorded in July during the rainy season in the southern part of the basin (OORBDA, 1982). The mean annual temperature is about $30^{\circ} \mathrm{C}$, which can varies depending on the location and time of the year (Ifabiyi, 2005). In general, relative humidity decreases northwards in the basin. The mean annual humidity varies from $75 \%$ in the south to $55 \%$ in the north (OORBDA, 1982).

The basin is underlain by two types of rocks which are the Basement Complex rocks and the sedimentary basins (Oke et al., 2013; OORBDA, 1982). About $93 \%$ of the basin is underlain by the Basement Complex rocks, while the remaining 7\% is sedimentary rock found in the southern part of 384 the basin close to the Atlantic (Ashaolu, 2016). The rock types are the intracrustal group (e.g. granite, gneisses, migmatite etc) and supracrustal (volcanic and sediments), while the lower part of the basin is covered by recent deposits that subdivide into the lithoral and lagoonal sediments of the coastal belts and the alluvial sediments of the major rivers (OORBDA, 1982). The soils belong to the highly ferruginous tropical red soils associated with Basement Complex rocks. As a result of the dense humid forest cover in the area, the soils are generally deep and of two types, namely, deep clayey soils formed on low smooth hill crests and upper slopes; and the more-sandy hill wash soils on the lower slopes (Ifabiyi, 2005). The relief of the basin is generally undulating and descends from an altitude of about 700 meters in Oke lmesi area to 50 meters and below in areas around Epe and Ibeju Lekki in the southern parts of the basin (Ashaolu, 2016).

The land use pattern within the drainage basin includes land use for residential/settlements and built up areas, bare rocks, bare surfaces, crops/shrubs, vegetation/forest and water bodies. Originally, almost all parts of the basin had a natural lowland tropical rain forest vegetation; but this has however, been replaced by secondary forest regrowth as a result of years of human occupation (Ifabiyi, 2005). The population distribution pattern of the basin is quite uneven. The urban population in the basin is larger than the rural population. Besides, available records from different 


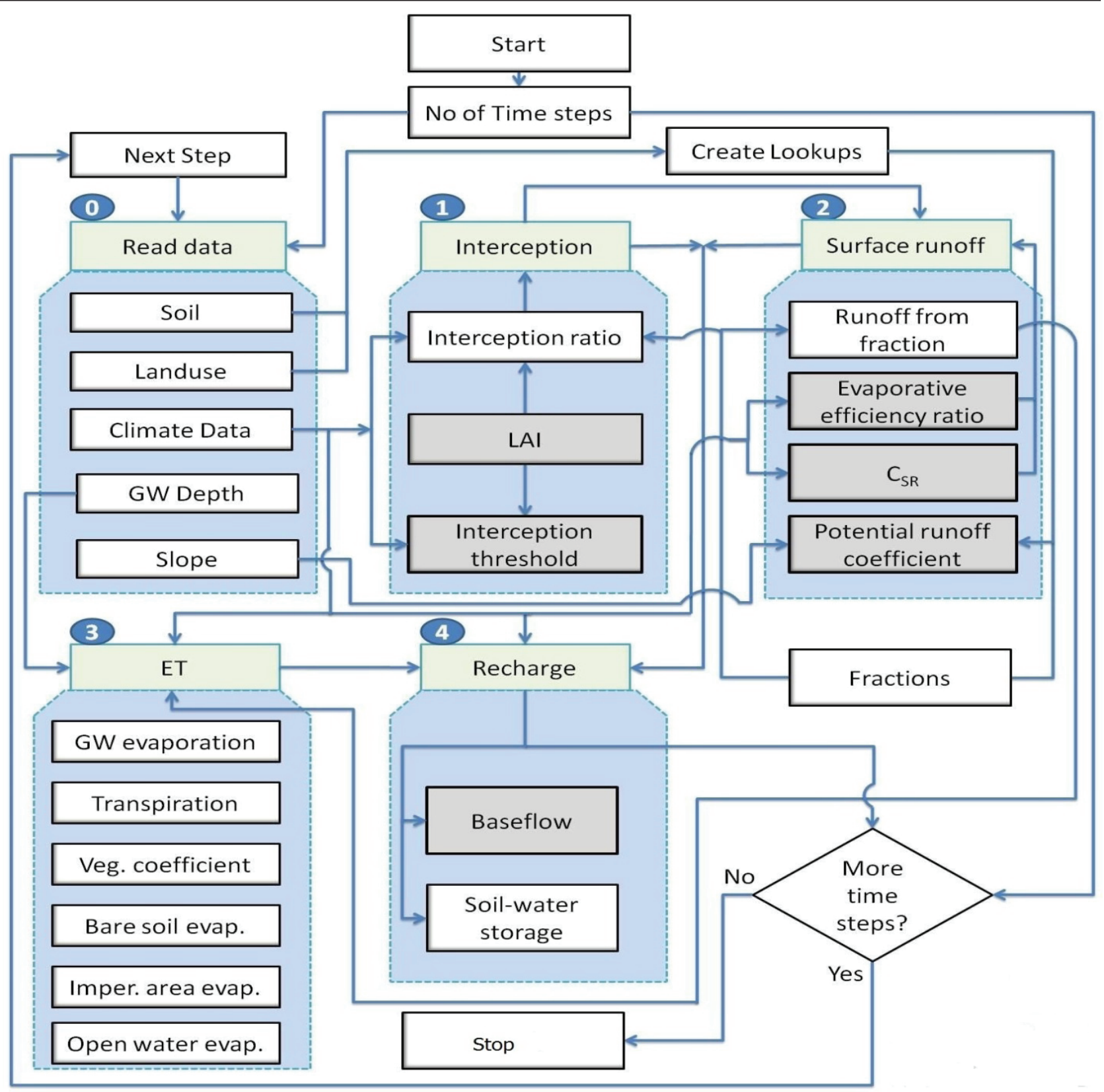

Fig. 2: Flowchart for Monthly Spatially Distributed Water Balance model, WetSpass-M

Source: Abdollahi et al., (2017)

investigations and surveys confirmed the constant movement of population from the rural areas to the cities. Based on the 1963 population census of western Nigeria, the estimated population of the basin made by Ogun-Oshun River Basin Development Authority in 1980 was 4,281,000 and this was estimated to be 12,046,145 in 2015 (Ashaolu, 2018).

Materials and Methods. WetSpaa-M hydrological model was used to estimate mean monthly groundwater recharge in the study area. Block scheme of the flowchart of WetSpass-M water balance model is presented in the figure 2. This model requires two types of input data. There are GIS grid maps and parameters tables (Batelaan and De Smedt, 2001). These grid maps include Digital Elevation Model (DEM), slope, land use/land cover, soil texture, depth to water and monthly climatic maps of rainfall amount, number of rainy days, temperature, potential evapotranspiration and wind speed (Abdollahi, 2015). All the input maps were provided in ESRI ascii grid format. The details on the formulation and application of the model can be found in Abdollahi et al. (2017). The climatic variables used in this study spanned between 1976 to 2015 and it was collected from the Nigeria Metrological Agency (NIMET). Also, Climate Forecast System Reanalysis (CFSR) data by the National Centers for Environmental Prediction (NCEP) were downloaded from https://globalweather.tamu.edu/ website. In all, the climatic variables from 24 weather stations across the study area were used in the study. Mean monthly values of rainfall amount, temperature, potential evapotranspiration and wind speed 
were calculated from the available data in each station. The digital maps of the monthly rainfall amount, temperature, potential evapotranspiration and wind speed were created by spatial interpolation of the values observed from the stations, using the universal kriging interpolation module of ArcGIS. The details of the climate preprocessing and data manipulations for the WetSpass-M model was discussed elsewhere (Ashaolu, 2018). The potential evapotranspiration for the same period was estimated using the FAO Penman-Monteith method (Allen et al., 1998).

The classified LULC maps of the study area for the period 1984, 2000 and 2015 were adopted for this study (Ashaolu, 2019). Seven land use/land cover classes such as bare surfaces, built up area, crops/shrubs, forest, rock outcrops, water bodies and wetland were adopted. These seven classes fall under four main category of land use/land cover (vegetated cover, bares soil, open water and impervious surfaces) recognized by WetSpass-M hydrological model. This was done to avoid land use heterogeneity within the pixel (Batelaan and De Smedt 2001; Ampe et al., 2012) and based on the influence such land use/land cover have on water balance of the area. Soil texture map was extracted from the harmonized world soil database version 1.2 (2012) prepared by the Food and Agriculture Organization of the United Nations (FAO) and others. Digital Elevation Model (DEM) with $30 \mathrm{~m}$ resolution of the study area was obtained from the Shuttle Radar Topography Mission (STRM) of the National Aeronautics and Space Administration (NASA). The slope map was processed from the DEM using ArcGIS. The mean depth to water in the study area reported in the Federal Ministry of Water Resources (FMWR) 2014 national water resource master plan report was adopted. Hence, $10 \mathrm{~m}$ depth to water was adopted for the $93.28 \%$ of the basin underlain by the Basement Complex rocks and $50 \mathrm{~m}$ for the remaining $6.67 \%$ underlain by the sedimentary basin in the south. Discharge data record was obtained from Ogun-Osun River Basin development Authority, Nigeria.

Land-use, soil and runoff characteristics are specified in four parameters tables required for the WetSpass model (Tesfamichael et al., 2013; Batelaan and De Smedt, 2001). These tables were connected to the maps as attribute tables. The land-use attribute table include parameters related to land-use type; such as rooting depth, leaf area index, vegetation height among many others. The soil parameter table contains soil parameters for each textural soil class as field capacity, wilting point, permeability and others. The runoff attribute tables contain parameters for runoff for all combinations of land-uses, slope, and soil type (Tesfamichael et al., 2013). The parameters in the soil types table are based on the United States Department of Agriculture (USDA) soil classification. Also, the runoff attribute table contains values considered to be universal, that is, a certain combination of slope, land-use, and soil type will produce a certain fraction of runoff independent of location (Tesfamichael et al., 2013). After the input data has been prepared, they were inputted into the model to begin the simulation of the monthly water budget of the Osun drainage basin using the LULC map of the year 2000. The outputs include several spatio-temporal (monthly and spatial distribution) hydrologic outputs such as interception, actual evapotranspiration, runoff and recharge. The model was calibrated manually using the following parameters: soil moisture alfa coefficient $(\alpha)$, LP a calibration parameter $(-)$ which reduces the potential evapotranspiration depending on the soil moisture (default is 0.65 ), interception parameter (a), and runoff delay factor (x) which were optimized according to the goodness of fit between the simulated runoff and the runoff from observed discharge at Apoje station. The calibration started with the soil moisture alfa coefficient (Abdollahi et al., 2017). The coefficient of determination $\left(\mathrm{R}^{2}\right)$ and the Nash-Sutcliffe model efficiency (NSE) were used for validation using the simulated and observed discharge data of 1999 at Apoje gauge station. The Pearson moment correlation coefficient of 0.71 exists between the observed and simulated surface runoff, while the Nash-Sutcliffe coefficient is 0.89 . However, the groundwater recharge which is the focus of this study was only reported.

After the calibration, to identify the effect of the LULC on groundwater recharge, all the necessary input parameters were inputted, then the simulation with WetSpass-M model was performed by keeping every other input parameter constant, while the land use/land cover of the three epochs (1984, 2000 and 2015) were used one after the other to run the model. This enabled the identification of the effects of land use/land cover changes over time on the groundwater recharge of the basin. This approach was adopted by Pan et al. (2011) and Albhaisi et al. (2013) to evaluate the effect of LULC change on groundwater recharge in Guishi River basin in China and Berg catchment in South Africa, respectively. The recharge on each LULC classes for the three periods (1984, 2000 and 2015) were isolated and aggregated in ArcGIS 10.4. The percentages of recharge occurring on each LULC were computed from the overall basin recharge for each period and the result compared. 
Results and Discussion. The sensitivity of LULC change on groundwater recharge in the basin is presented in Table 1. The LULC with highest groundwater recharge in 1984, 2000 and 2015 was on forest land cover which are $48.56 \%, 33.64 \%$ and $37.29 \%$, respectively. This might be due to the influence of vegetation in slowing down the speed of running water across the forest area, that allows more infiltration increase in total annual groundwater recharge occurrence in built up area from $9.46 \%$ to $10.29 \%$. The significant increase in built-up areas from $4.64 \%$ in 2000 to $10.72 \%$ in 2015 resulted to the built-up area doubling its size. During this period, the relative contribution of built up area to groundwater recharge only increased meagerly from $10.29 \%$ to $10.81 \%$. The groundwater recharge occurrence on built-up area

Table 1. Effect of each LULC Classes Change on Groundwater Recharge

\begin{tabular}{|c|c|c|c|c|c|c|c|}
\hline \multirow{2}{*}{\multicolumn{2}{|c|}{$\begin{array}{c}\text { Land Use/Land } \\
\text { Cover Types } \\
\%\end{array}$}} & $\begin{array}{l}1984 \\
L U L C\end{array}$ & $\begin{array}{c}1984 \\
\text { Groundwater } \\
\text { Recharge per } \\
\text { LULC }\end{array}$ & $\begin{array}{l}2000 \\
L U L C\end{array}$ & $\begin{array}{l}2000 \text { Ground- } \\
\text { water Recharge } \\
\text { per LULC }\end{array}$ & $\begin{array}{l}2015 \\
L U L C\end{array}$ & $\begin{array}{l}2015 \text { Groundwater Re- } \\
\text { charge per LULC }\end{array}$ \\
\hline & & $\%$ & $\%$ & $\%$ & $\%$ & $\%$ & \\
\hline 1 & Bare Surfaces & 20.56 & 20.69 & 27.30 & 24.76 & 31.10 & 25.98 \\
\hline 2 & Built Up Areas & 3.20 & 9.46 & 4.63 & 10.29 & 10.72 & 10.81 \\
\hline 3 & Crops/Shrubs & 16.58 & 7.55 & 41.94 & 19.28 & 31.38 & 19.48 \\
\hline 4 & Forest & 52.62 & 48.56 & 20.75 & 33.64 & 21.71 & 37.29 \\
\hline 5 & Rock Outcrops & 4.97 & 4.49 & 3.45 & 3.09 & 4.23 & 2.44 \\
\hline 6 & Water Bodies & 0.51 & 0.00 & 0.62 & 0.00 & 0.62 & 0.00 \\
\hline 7 & Wetland & 1.55 & 9.25 & 1.32 & 8.93 & 0.24 & 4.00 \\
\hline
\end{tabular}

and deep percolation into the water table. The result agrees with the study of Zamlot et al. (2015) that discovered that forest land-use type have a positive higher effect on groundwater recharge, in Flanders, Belgium. High recharge in the forested area in the basin can be attributed to the preferential flow mechanism through the unsaturated zone. Preferential flow is often associated with tree roots that have created preferential path ways/macro pores in the unsaturated zone with a relatively high infiltration and percolation capabilities (Obuobie, 2008; Lerner et al., 1999; 1990) that allows rainfall easy passage into the saturated zone to recharge the groundwater system.

The least groundwater recharge in relation to LULC for the three periods was on the rock outcrops, while no recharge takes place on the water bodies. About $4 \%, 3 \%$ and $2 \%$ of the total annual recharge occurred on the rock outcrops in 1984, 2000 and 2015 , respectively. This is because recharge can only occur on this type of LULC classes in the interface between the outcrops and the loose cracks found around the flat area of the rock outcrops. The least recharge found on rock outcrops is expected and may be attributed to the fact that infiltration can only occur around or on decomposed rock outcrop, which may result in minute recharge to the groundwater system.

Built-up area increases slightly from $3.20 \%$ in 1984 to $4.64 \%$ in 2000 , which resulted in slight did not increased in relation to its size as observed between 1984 and 2000. This suggests that there are more paved surfaces within the built-up expansion by the year 2015. In other words, the spatial expansion of built up area by 2015 in the basin have more impervious surfaces that prevent water to infiltrate and percolate to recharge the groundwater system in and around the built-up areas like the preceding years. The result differs from that of Dams et al. (2008) that used four LULC change between 2000 and 2020, where they observed a reduced recharge in urban centres. The mean monthly occurrence of groundwater recharge in built up LULC class in 1984, 2000 and 2015 is presented in Fig. 3.

Groundwater recharge occurrence on crops/ shrubs LULC classes increased from $7.53 \%$ to $19.28 \%$ between 1984 and 2000 . The $11.25 \%$ increase in groundwater recharge occurrence on this LULC type, was a consequence of significant increase in crops/ shrubs between the same period. Despite about $10 \%$ decrease in crops/shrubs between 2000 and 2015, less than $1 \%$ increase in groundwater recharge occurrence was still discovered. Groundwater recharge varies over space in all the LULC classes, with some areas of crops/ shrubs LULC having little to zero recharge. Therefore, about $10 \%$ area of crops/shrubs converted to another use by 2015 might be those areas with little or no recharge. A similar low increase on crops and shrubs 


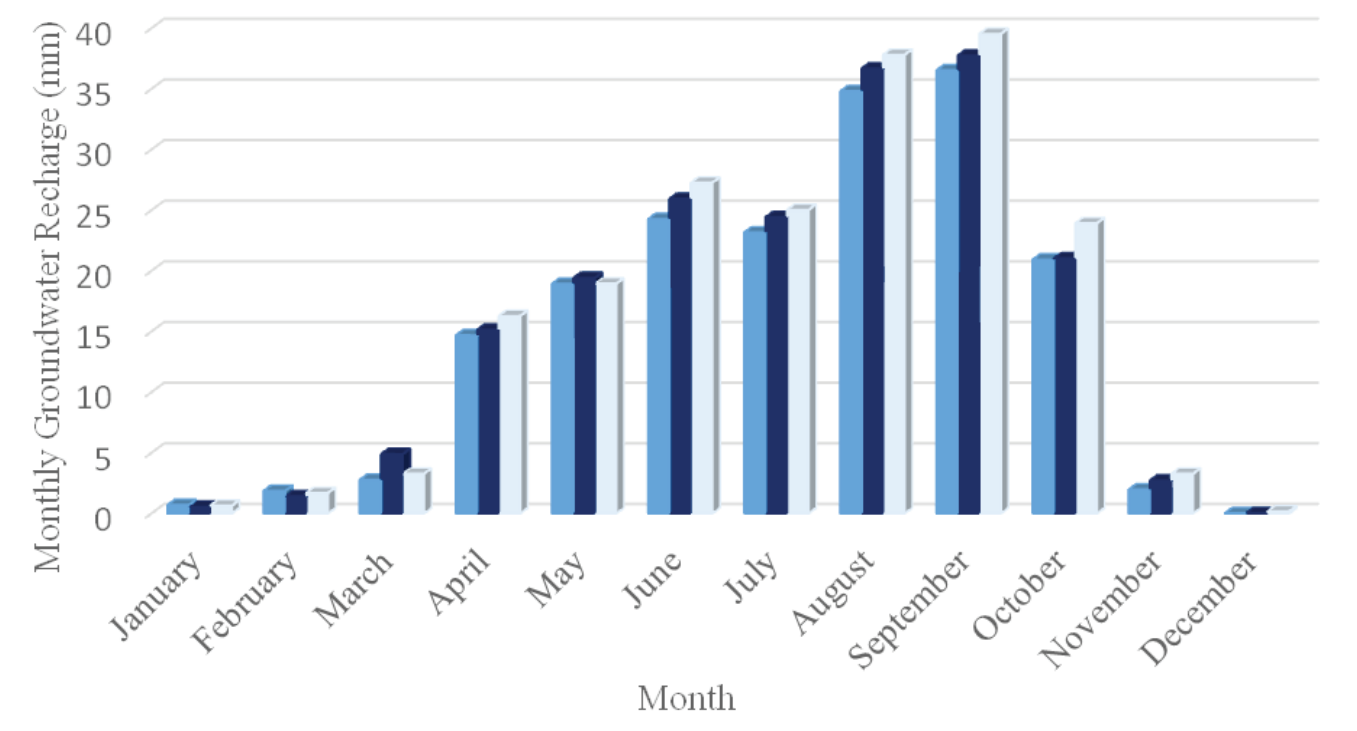

Groundwater Recharge 1984 Groundwater Recharge 2000 Groundwater Recharge 2015

Fig. 3: Mean Monthly Recharge on Built UP Area LULC Class

LULC was observed in upper Berg catchment, South Africa (Albhaisi et al., 2013). The monthly occurrence of groundwater recharge in 1984, 2000 and 2015 on crops/shrubs LULC class is presented in Fig. 4.

The occurrence of groundwater recharge in
2000 is similar to the study of Albhaisi et al. (2013) in South Africa between 1984 and 2009. Forest area later increased slightly between 2000 and 2015, which also increased groundwater recharge occurrence on forest LULC from $33.64 \%$ to $37.29 \%$. About $4 \%$

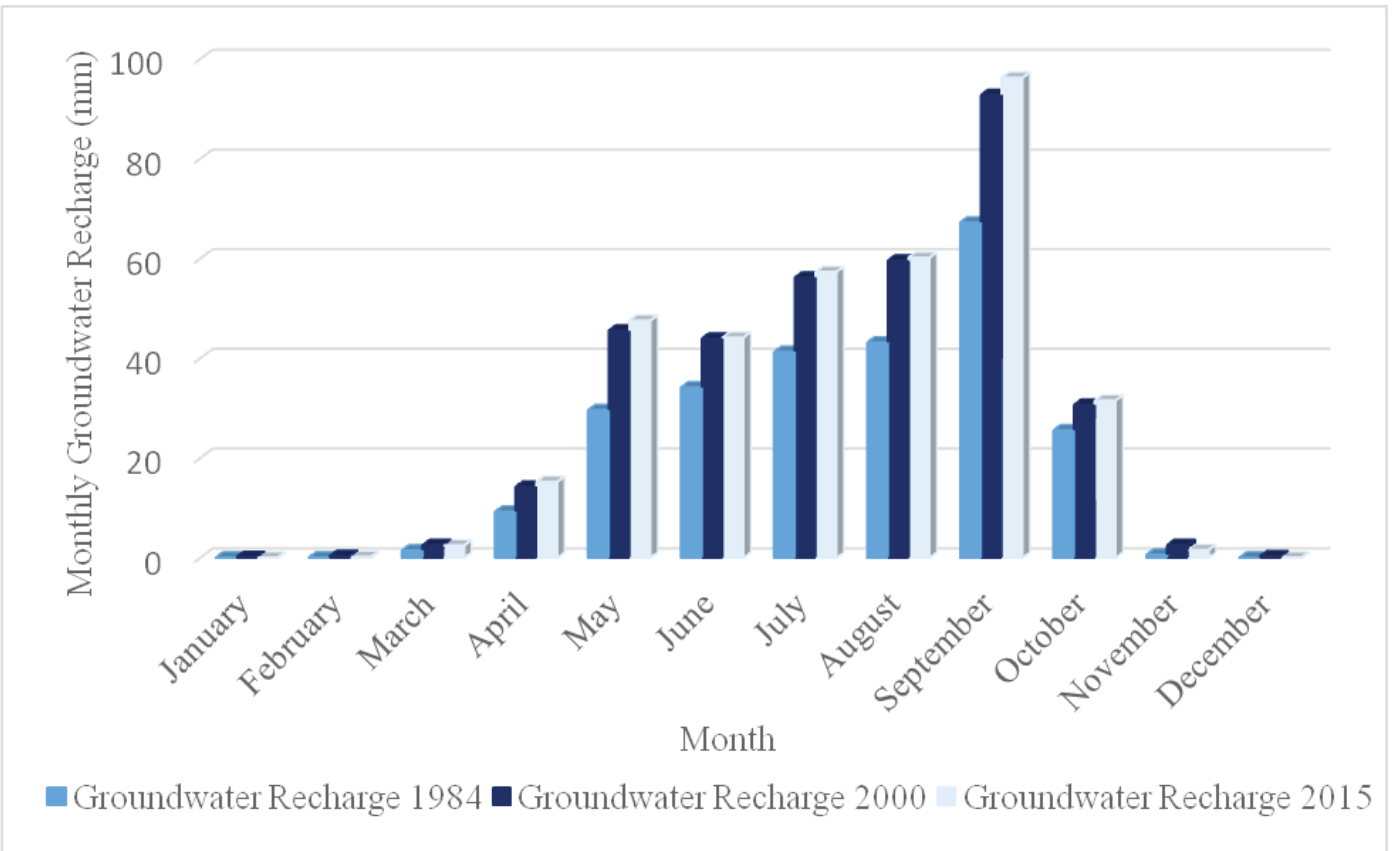

Fig. 4: Mean Monthly Recharge on Crop/Shrubs LULC Class

forest area decreased from $48.56 \%$ in 1984 to $33.64 \%$ in 2000 . During this period, the forested area declined significantly as a consequence of human anthropogenic activities in the basin. As it was noted earlier that highest recharge was found in forest area, increased deforestation signals reduced recharge in the basin. The result obtained between 1984 and increase in ground water recharge can be attributed to the slight increase in forest area that lead to reduced overland flow, more infiltration and percolation to the groundwater table to recharge the aquifer. Fig. 5 shows the monthly contribution of forest LULC class to groundwater recharge in 1984, 2000 and 2015 in the basin. 


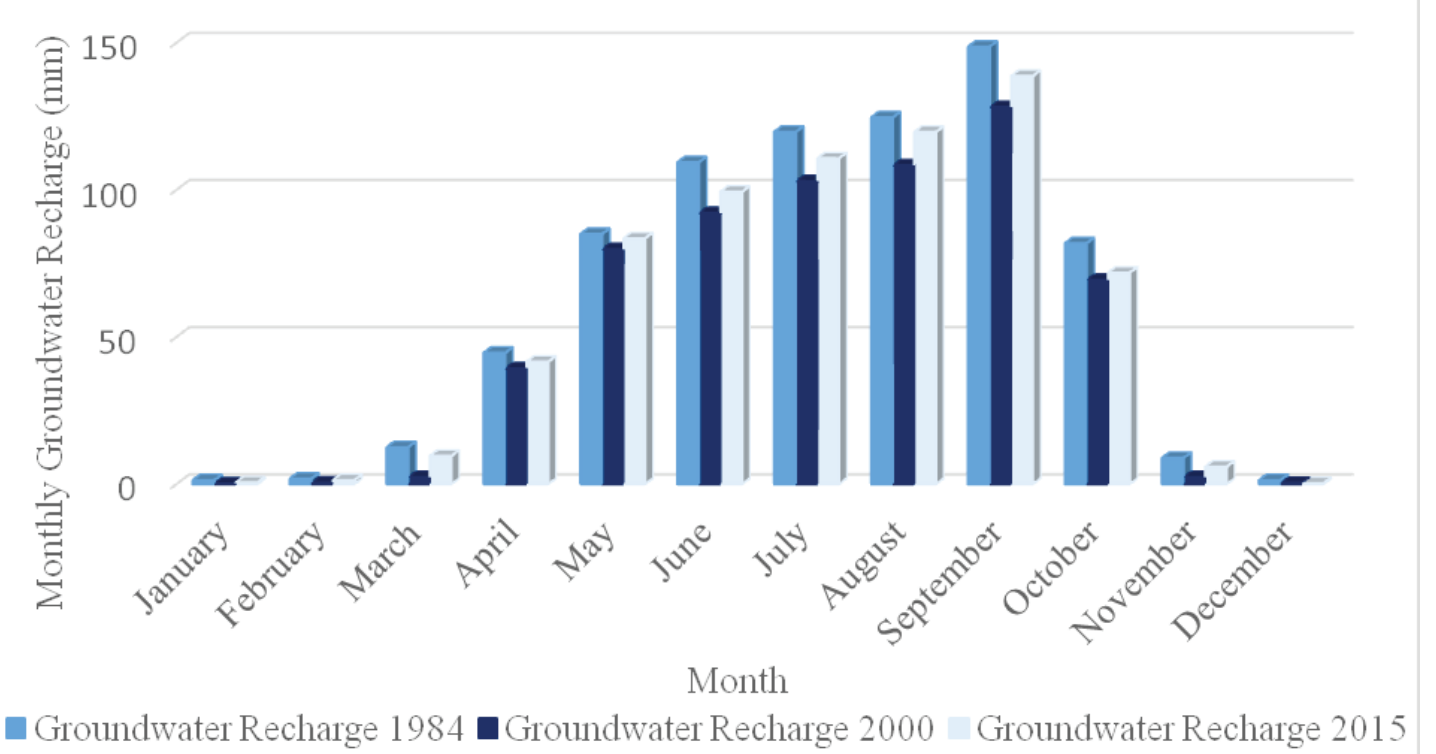

Fig. 5: Mean Monthly Recharge on Forest LULC Class

Groundwater recharge occurrence on bare surface increased from $20.69 \%$ to $24.76 \%$ between 1984 and 2000, while it increased further to $25.98 \%$ in 2015. This was an increase of $4.07 \%$ in groundwater recharge between 1984 and 2000, while it was $1.22 \%$ increase between 2000 and 2015. The relatively small increase rate of recharge occurrence on this LULC is as a result of less than $6.74 \%$ and $4 \%$ increase in areal coverage of bare surface between 1984 and 2000; and from 2000 to 2015 , respectively. The minute increase may be attributed to the fact that bare land use tripled its areal extent of 1984 by the year 2008. The monthly occurrence of groundwater recharge in bare LULC class in 1984, 2000 and 2015 is presented in Fig. 6.

Wetland decreased from $1.55 \%$ in 1984 to $1.32 \%$ in 2000, which accounted for slight reduction in groundwater occurrence from $9.25 \%$ to $8.98 \%$. Also, wetland decreased from $1.32 \%$ in 2000 to $0.24 \%$ in 2015 , which was about $1.08 \%$ reduction in wetland between the period. The change in wetland leads to

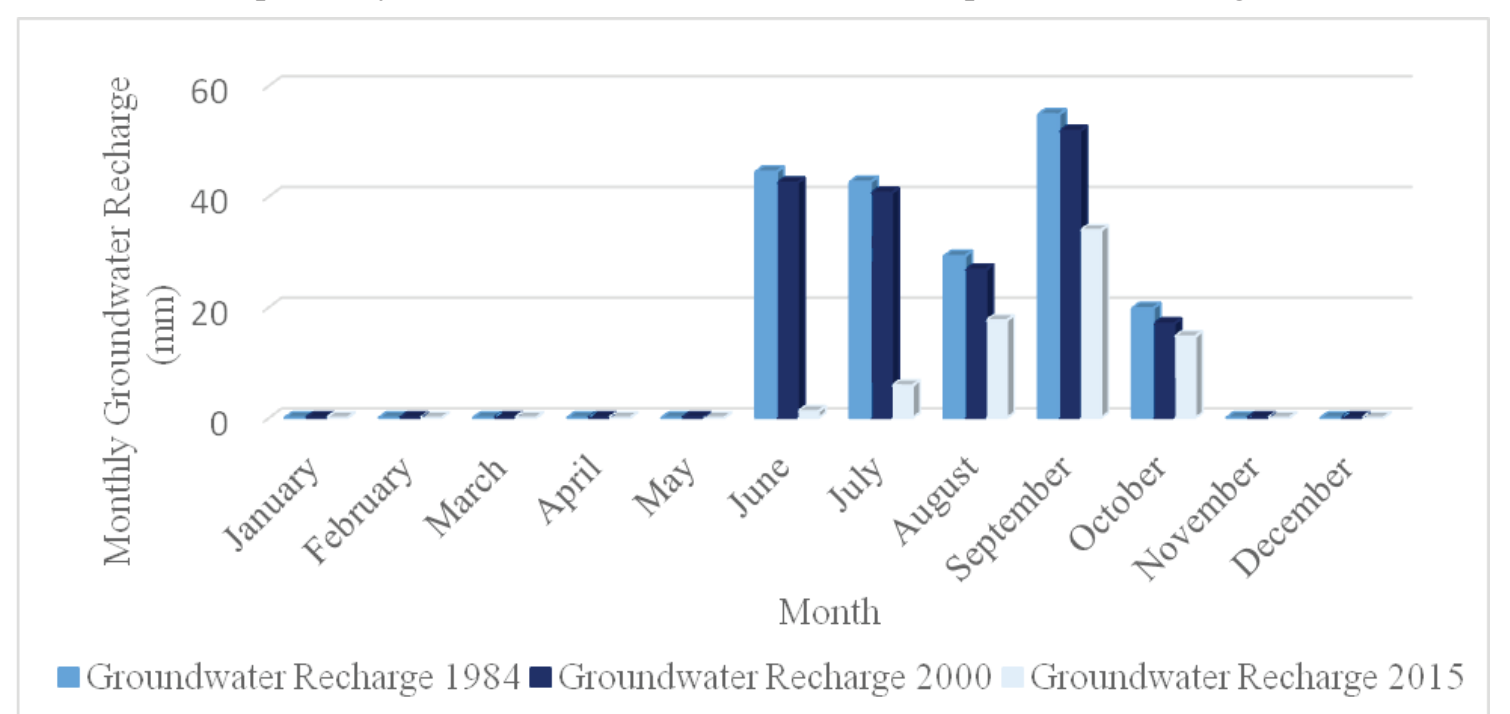

Fig. 6: Mean Monthly Recharge on Bare Surfaces LULC Class

in recharge occurrence on bare surface in Osun drainage is at variant with the observation of Albhaisi et al. (2013) in upper Berg catchment, South Africa, where groundwater recharge on bare LULC class increases significantly from $23 \%$ in 1984 to $64.7 \%$ in 2008. The significant increase observed in their study reduction in groundwater recharge on wetland from $8.93 \%$ in 2000 to $4.00 \%$ in 2015 . This was slightly more than $50 \%$ reduction in groundwater recharge occurrence on wetland as a result of about $1.08 \%$ change in wetland LULC between 2000 and 2015. Monthly contribution of wetland LULC class to 


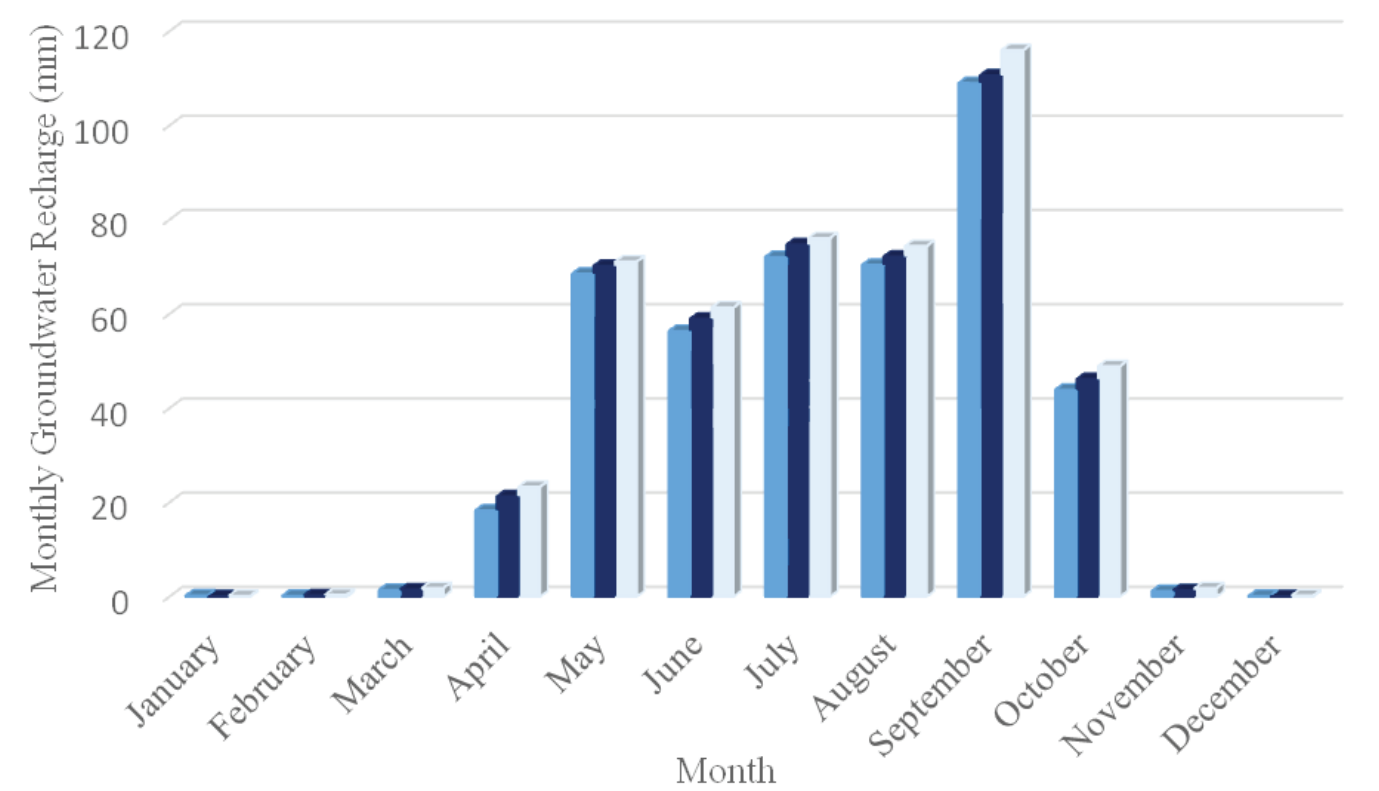

aroundwater Recharge 1984 Groundwater Recharge 2000 Groundwater Recharge 2015

Fig. 7: Mean Monthly Recharge on Wetland LULC Class

groundwater recharge in 1984, 2000 and 2015 is presented in Fig. 7.

The mean annual groundwater recharge of the basin for the land use maps of 1984, 2000 and 2015 in the basin. As the main source of replenishment of the groundwater resources, groundwater recharge over time and space in a Basement complex aquifer determines the groundwater reserve. Hence, it can

Tab. 2: Overall Effect of LULC Change on Groundwater Recharge in the Entire Basin

\begin{tabular}{|l|l|c|c|c|c|}
\hline Sn & \multirow{2}{*}{ Years } & $\begin{array}{c}\text { Mean Annual } \\
\text { Recharge }\end{array}$ & \multicolumn{4}{|l|}{ Change in Groundwater Recharge } \\
\cline { 4 - 6 } & & & Period & $\mathrm{mm}$ & $\%$ \\
\hline 1. & 1984 & 476.54 & $1984-2000$ & -65.40 & -13.72 \\
\hline 2. & 2000 & 411.07 & $2000-2015$ & +18.99 & +4.61 \\
\hline 3. & 2015 & 430.06 & $1984-2015$ & -46.48 & -9.75 \\
\hline
\end{tabular}

- signifies decrease in groundwater recharge

+ signifies increase in groundwater recharge

are $476.54,411.07$ and $430.06 \mathrm{~mm} / \mathrm{y}$, respectively is presented in Table 2. This shows that mean annual groundwater recharge decreased by $13.72 \%$ between 1984 and 2000, while it increased by $4.61 \%$ between 2000 and 2015. There was a general decrease of $9.75 \%$ in mean annual groundwater recharge between 1984 and 2015. As stated earlier, the forest area decreased from its areal extent of $5223.61 \mathrm{~km}^{2}$ in 1984 to $2154.87 \mathrm{~km}^{2}$ in 2015 . The observed decrease in groundwater recharge can be attributed to a larger extent to the deforestation of the tropical rainforest under which highest groundwater recharge occurred be deduced that the groundwater reserve of the basin declined with about $10 \%$ between 1984 and 2015 as a result of change in LULC. The result is at variant with the observation of Albhaisi et al. (2013) in upper Berg catchment, South Africa where an increase in groundwater recharge of about $8 \%$ was observed between 1984 and 2008. The reason for the variance in results is that highest groundwater recharge occurrence was found in the forest area in this present study which has decreased to $21.71 \%$ by 2015 , while, highest groundwater recharge occurred in bare land which has increased to $65 \%$ of the Berg catchment 


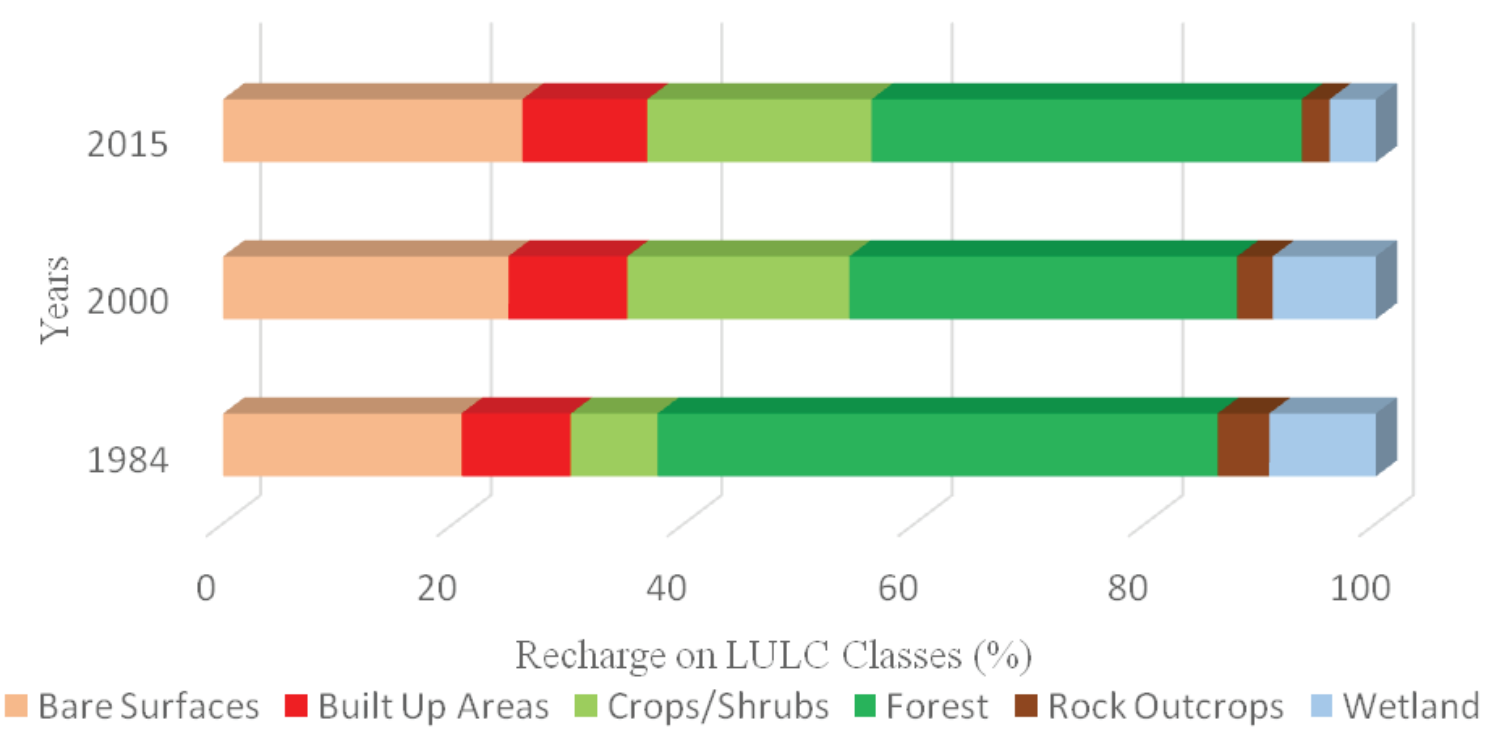

Fig. 8: Mean Annual Groundwater Recharge Occurrence on Different LULC Classes

by 2008 .

The effect of LULC change on groundwater recharge in Osun drainage basin indicates that there are only little changes in recharge to groundwater system that can be associated to change in LULC. However, change in LULC have resulted to changes in recharge pattern in the basin. The reasons for the observed change in recharge pattern can be attributed to the fact that most often, change in LULC is a transition from one LULC class to another. The recharge pattern is influenced based on the amount and degree of transition taking place and the characteristics of the dominant LULC at a particular area of the basin. This correspond to Finch (2001) when he observed in a rural catchment of southern England that the mean annual groundwater recharge response to land cover change led to changes in the recharge pattern. Fig. 8 shows the percentages of the mean annual groundwater recharge occurrence on different LULC classes of 1984, 2000 and 2015 in Osun drainage basin.

Nevertheless, it is important to note that the percentage contribution of the seven LULC classes to groundwater recharge was based on the mean of groundwater recharge observed on each LULC class in the basin. Looking at it from the spatial perspective, a relatively higher change in recharge occurred on some LULC classes between 1984, 2000 and 2015. For example, the recharge amount occurrence on bare surface LULC in September 2000 in the northeastern and northcentral part of the basin in Oke Imesi, Efon Alaaye, Osogbo, Ede and Ilesha ranged between $118.45 \mathrm{~mm}$ to $174.59 \mathrm{mmm}$. In 2015 , bare surface in the same part of the basin contributed groundwater recharge that ranged between $121.54 \mathrm{~mm}$ to $138.61 \mathrm{~mm}$ (Fig. 9). This revealed the change in spatial pattern of groundwater recharge as a result of change in LULC classes.

Conclusion. The effect of LULC change on groundwater recharge of Osun drainage basin was examined in this study. The contribution of each LULC class to groundwater recharge were examined for the years 1984, 2000 and 2015. The change in LULC between 1984, 2000 and 2015 influence only the recharge pattern but with little effect on the overall groundwater recharge in the basin. The groundwater recharge between 1984 and 2015 revealed a decrease of about $10 \%$. This decrease was associated with decrease in forest area where larger percentage of groundwater recharge takes place in the basin. The continued deforestation of the forested area under which higher percentage of groundwater recharge occurred will not only pose a significant threat to groundwater reserve, but also to streamflow maintenance during dry months and the ecosystem of the basin in general. The average annual rate of change (decrease) in forest area for the 32 -year period was $1.84 \%$, which resulted to about $10 \%$ decrease in groundwater recharge for the period investigated. The $10 \%$ overall decline in groundwater recharge might become pronounced if the current rate of deforestation continues in the basin unabated. Therefore, a proper land use allocation and change strategy in sustainable management of groundwater resources becomes paramount. The afforestation in terms of planting of native trees that were lost through anthropogenic activities in the basin should be policy option for groundwater sustainability, because highest groundwater recharge occurred in forested area of the basin.

Acknowledgement. This article is a part of the Ph.D. thesis of the principal author. Anonymous reviewers 


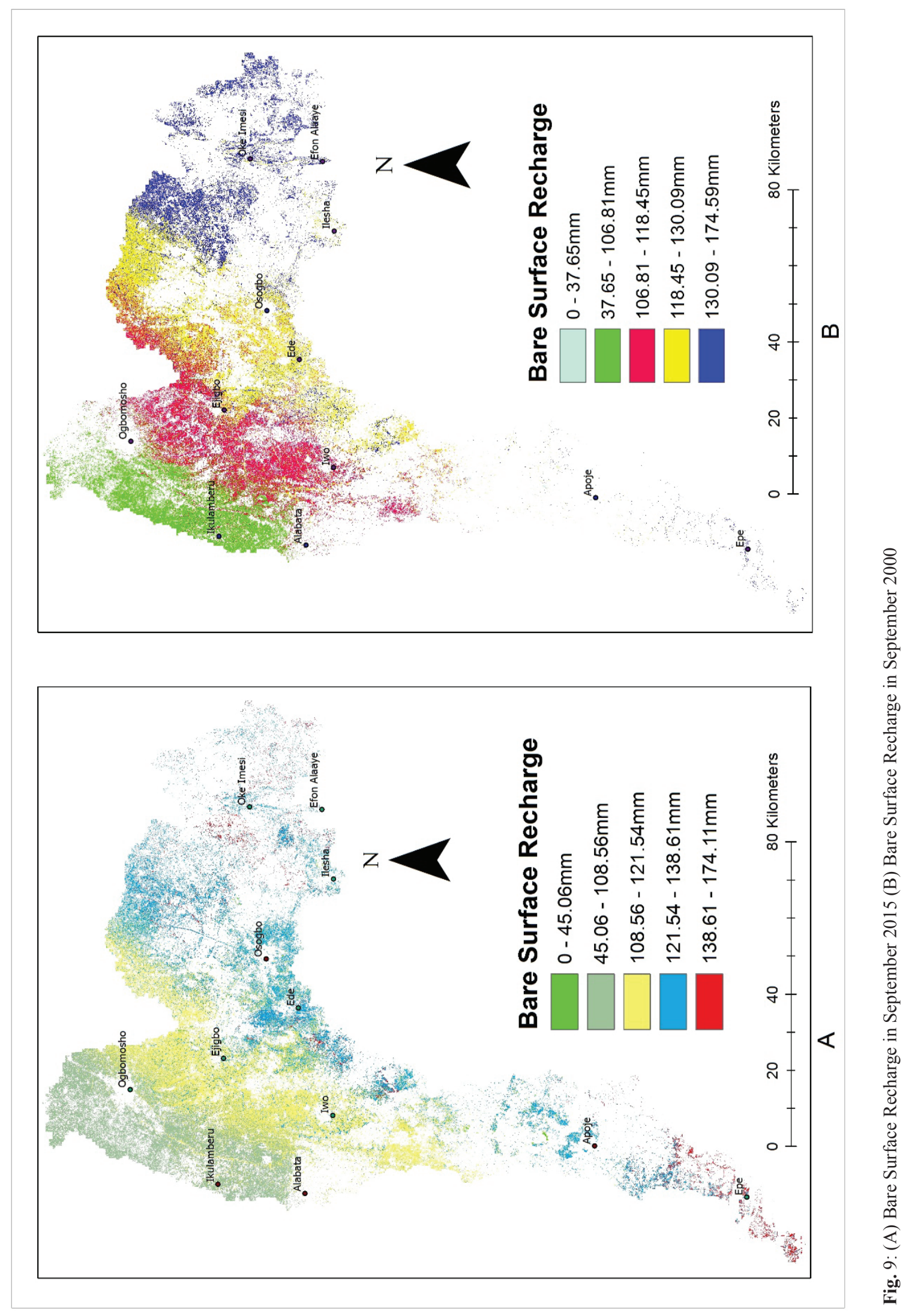


are greatly appreciated.

\section{References}

Abdollahi, K., Bashir, I., Verbeiren, B., Harouna, M. R., Griensven, V., Huysmans, M., Batelaan, O. 2017. A distributed monthly water balance model: Formulation and application on Black Volta Basin. Environmental Earth Science, 76,1-18.

Akinyemi, F. O. 2005. Mapping land use dynamics at a regional scale in southwestern Nigeria. Retrie-ved from www.isprs.org/proceedings/2005/hannover05/paper/149-akinyemi.pdf on 22/08/2016.

Albhaisi, M., Brendonck, L., Batelaan, O. 2013. Predicted impacts of land use change on groundwater recharge of the upper Berg catchment, South Africa. Water SA, 39(2), 211-220.

Allen, R., Pereira, L. A., Raes, D., Smith, M. 1998. Crop evapotranspiration. In FAO irrigation and drainage paper No. 56; FAO: Rome, Italy.

Ampe. E. M., Vanhamel, I., Salvadore, E., Dams, J., Bashir, I., Demarcchi, L...Batelaan, O. 2012. Impact of land-cover classification on groundwater recharge uncertainty. IEEE Journal of Selected Topics in Applied Earth Observations and Remote Sensing, 5(6), 1859-1867.

Ashaolu, E. D. 2016. The Osun drainage basin in the western lithoral hydrological zone of Nigeria: A morphometric study. GEOGRAFIA-Malaysian Journal of Society and Space, 12 (8), 71-88.

Ashaolu, E. D. 2018. Effect of climate and land use/land cover change on groundwater recharge in Osun drainage basin, Nigeria. (Ph.D. Thesis), University of Ilorin, Ilorin, Nigeria.

Ashaolu, E. D., Olorunfemi J. F. and Ifabiyi, I. P. (2019). Assessing the spatio-temporal pattern of land use and land cover changes in Osun drainage basin, Nigeria. Journal of Environmental Geography, 12 (1-2), 41-50.

Batelaan, O., De Smedt, F. 2001. WetSpass: A flexible, GIS Based, distributed recharge methodology for regional groundwater modeling, In Gehrels, H., Peters, J., Hoehn, E., Jensen, K., Leibundgut, C., Griffioen, J., Webb, B., \& Zaadnoordijk, W-J. (Eds.), Impact of human activity on groundwater dynamics (269, 11-17). IAHS Publication.

Brauman, K. A., Freyberg, D. L., Daily, G.C. 2012. Land cover effects on groundwater recharge in the tropics: ecohydrologic mechanisms. Ecohydrolgy. 5, 435-444.

Brauman K.A., Daily, G.C., Duarte, T.K., Mooney, H.A. 2007. The nature and value of ecosystem services: an overview highlighting hydrologic services. Annual Review of Environment and Resources, 32, 67-98.
Dams, J., Woldeamlak, S.T., Batelaan, O. 2008. Predicting land-use change and its impact on the groundwater system of the Kleine Nete catchment, Belgium. Hydrology and Earth System Sciences, 12, 1369-1385.

DeFries, R., Eshleman, K.N. 2004. Land-use change and hydrologic processes: a major focus for the future. Hydrological. Processes. 18, 2183-2186.

Federal Ministry of Water Resources 2014. The project for review and update of Nigeria national water resources master plan. Official Dissemination Version, Volume 6, prepared by Japan International Cooperation Agency (JICA).

Finch, J. W. 2001. Estimating change in direct groundwater recharge using a spatially distributed soil water balance model. Quarterly Journal of Engineering Geology and Hydrogeology, 34, 71-83.

Foster, S., Cherlet, J. 2014. The links between land use and groundwater - Governance provisions and management strategies to secure a 'sustainable harvest'. Global Water Partnership perspective paper. Retrieved from https://www.gwp.org/globalassets/global/toolbox/publications/perspective-papers/perspective paper landuse and groundwater_no6_english.pdf. on 23/06/2016.

Gasu, M. B., Nicholas, E., Bidmus, M. A., Dawam, P. D. 2016. Geospatial analysis of land use dynamics in Osogbo between 1986 and 2012. Abuja Journal of Geography and Development, 4(1), 52-68.

Ifabiyi, I. P. 2005. Construction versus yield of deep wells in the regolith aquifer of Osun River basin, Nigeria. Water Resources, 16, 1-16

IFAD (2010) Linking land and water governance. International Fund for Agricultural Development Information Note (Rome, Italy).

Lerner, D. N., Issar, A. S., Simmers, I. (Eds.) 1990. Groundwater recharge: A guide to understanding and estimating natural recharge. Heise, Hannover.

Lerner, D. N., Yang, Y., Barrett, M. H., Tellam, J. H. 1999. Loadings of non-agricultural nitrogen in urban groundwater. impacts of urban growth on surface and ground waters. Proceedings of IAHS symposium HS5, Birmingham, July 1999. IAHS publication. 259, 117-123.

Mengistu, D. A., Salami, A. T. 2007. Application of remote sensing and GIS in land use/land cover mapping and change detection in a part of southwestern Nigeria. African Journal of Environmental Science and Technology, 1 (5), 99-109.

Obuobie, E. 2008. Estimation of groundwater recharge in the context of future climate change in the White Volta River basin, West Africa. (Ph.D. Dissertation), University of Bonn, Germany.

Oke, M. O., Martins, O., Idowu, O., Aiyelokun, O. 2013. Comparative analysis of empirical formulae used in groundwater recharge in Ogun-Oshun River basins. Journal of Scientific Research \& Reports, 
2(2), 692-710.

Omorinbola, E. O. 1982. Systematic decline of groundwater level in the regolith of the Nigeria Basement Complex due to human activities, Proceedings of Exeter Symposium (Improvement of methods of long term prediction of variations in groundwater resources and regimes due to human activity), July 1982, IAHS Publication, no. 36.

Ogun-Oshun River Basin Development Authority 1982. Osun River basin feasibility study. Vol.7, May, 1982.

Pan, Y., Gong, H., Zhou, D., Li, X., Nakagoshi, N. 2011. Impact of land use change on groundwater recharge in Guishui River basin, China. Chinese Geographical Science, 21(6), 734-743.

Sala, O.E., Chapin, F.S.I., Armesto, J.J., Berlow, E., Bloomfield, J., Dirzo, R., Huber-Sanwald, E., Huenneke, L.F., Jackson, R.B., Kinzig, A., Leemans, R., Lodge, D.M., Mooney, H.A., Oesterheld, M., Poff, N.L., Sykes, M.T., Walker,
B.H., Walker, M., Wall, D.H. 2000. Global biodiversity scenarios for the year 2100 . Science, 287, 1770-1774.

Salami, A. T. (1995). Structural changes in vegetal cover in Ife and Ede regions of southwestern Nigeria between 1963 and 1993. (Ph.D. Thesis), Obafemi Awolowo University, Ile-Ife.

Salami, A. T, Ekanade, O., Oyinloye, R. O. 1999. Detection of forest reserve incursion in south-western Nigeria from a combination of multi-data aerial photographs and high-resolution satellite imagery. International Journal of Remote Sensing, 20(8), 1487-1497.

Tesfamichael G., De Smedt, F., Walraevens, K., Gebresilassie, S., Hussien, A., Hagos, M... Gebrehiwot, K. 2013. application of a spatially distributed water balance model for assessing surface water and groundwater resources in the Geba basin, Tigray, Ethiopia. Journal of Hydrology, 499. 110-123.

Vorosmarty, C.J., Green, P., Salisbury, J., Lammers, R. 2000. Global water resources: vulnerability from climate change and population growth. Science, 289, 284-288. 